\title{
Managing the Urban Change: A Morphological Perspective for Planning
}

\begin{abstract}
This study questions the awareness of planners on the intrinsic qualities of the built environment in shaping of urban form in Turkey throughout a centennial period after foundation of Turkish Republic in 1923. It suggests a morphological framework, to develop such an evaluation, which is based on three basic principles: the historicity of urban forms, the hierarchical nesting of urban form elements, and their reconciliation within a complex interaction with each other in a part-to-whole relationship. It is regarded as an initial attempt to develop a brief discussion about a morphological perspective to be utilized in planning practice. It is asserted that the centennial development of planning practice in Turkey brought to light that the professionals lost their concern on the intrinsic qualities of urban form, on how it is evolved historically, and on how its elements are related to each other. They abandoned themselves to the relative ease of application of insensitive planning with high confidence on the decency and convenience of procedural functioning of planning. It reveals that there is a need for a morphological perspective that would take into account the morphological unity of urban form elements within their interplay in order to develop a responsive planning approach.
\end{abstract}

Keywords: Morphological research, planning practice, morphological unity, part-to-whole relationship

*Assoc. Prof. Dr., Department of city and Regional Planning, Mersin University ORCID Email: tolgaunlu@gmail.com 


\section{INTRODUCTION}

In the last few decades, a number of studies in the field of urban morphology focused on the relationship between research and practice on the shaping of urban form. It has been one of the more important developments and one of the more significant opportunities for future development in urban morphology (Whitehand 2019). A very recent research, conducted through the responses of ISUF (International Seminar on Urban Form) members to a survey, revealed that the relationship between research and practice is one of the most remarkable categories within the field of urban morphology. Although most of the members prioritized urban morphology in understanding how urban forms are produced, stratified and modified, they also admitted that urban morphology has the potentiality to provide sound base to intervene in the process of urban development, and to manage the urban change in a better way (Barke 2019).

The central interest of this growing category is on the gap between the urban morphological research and planning and urban design practice (Gu, 2018). The reasons for such a gap has been stated in numerous ways: the complexity of vocabulary of urban morphology, insufficient demonstration of relevant methods to professionals, the dispersal of urban morphology across several disciplines (Samuels, 2019a); the reluctance to give a proper place to urban morphology in the education system of planning and architecture schools (Whitehand 2005, 2012); the unaware attitude of morphological agents (Samuels 1990; Whitehand 2007); unpopularity of urban morphology as a source of practice (Scheer 2008); requirement for much more time for research (Larkham 2006) and insufficient communication among different agents also may effect emergence of the gap between research and practice. In the same manner, Barke (2015) points out that the main reason behind this gap is the growing distance between academics and practitioners. While the former are criticized to be facing to engage with the real world, the latter are usually in search for solutions for short terms. Since the academicians get more specialized to get more points on a particular realm of research, practitioners become increasingly managerial, that distance between them continues to grow (Samuels, 2019b).

It is claimed in this study that the planners know very little about the intrinsic qualities of the urban space as the subject matter of their field of occupation. They are repeating their actions without 
or with little attention to the essential nature of urban space. That is to say, they usually act by rote in the planning process, and prefer to rely on the established procedures, written as rules to follow in the legislation. Consequently, they did not develop their intelligence on how urban forms are articulated in the historical and cultural development of societies and how to develop better interventions to deal with the urban change and to create successful urban environments. It is accepted that the successfulness can be achieved to the extent if the rules in planning legislation are followed without a question. This kind of planning is named in this study 'insensitive planning', in which high reliance on procedural aspects of planning and seeking quantitative measures of the legislation make planners oblivious and insensible to the qualities of the built environment, the subject matter they are supposed to initiate decisions on how to develop it. The priority is given to the piecemeal production of freestanding buildings without any control of a broader context.

Dominance of insensitive planning in any planning system and its application on urban development usually results in standardized urban environments that do not give response to the local context. This condition is defined as a crisis in the production of the built environment by Muratori (Cataldi, 2003). It is the 'loss of human scale' in the built environment (Conzen 1975), 'sacking of cities' (Jacobs 1961), 'antispaces' (Trancik 1986), 'placelessness' (Jacobs and Appleyard 1987).

This study questions the attitude of planners to what extent they are aware of the nature of the morphological characteristics of the city in their practice, and aims to contribute to development of a morphological perspective for planning. It takes Turkish planning practice in its centennial development, from the beginning of the young Turkish Republic, to scrutinize the attitude of planners whether they utilized a morphological perspective in dealing with urban change, intentionally or unintentionally.

\section{A Morphological Perspective for Planning}

A morphological perspective for planning is suggested in this part of the study in order to develop a more vigorous investigation into the planning practice. It relies on three basic principles (Moudon 1997). First, urban forms develop in their historicity, they are context-based and culturally bound and open to modifications through continuous morphological processes as a response to the changing needs, expectations and value judgements of the society. Second, the basic elements of urban form -plots, buildings and 
streets (Barke 2015, Conzen, 1969 [1960], Oliveira 2016, Kropf 2017, Whitehand 2001)- are interrelated to each other within a complex interaction that creates spatially distinct areas in the city. Third, the elements of urban form function within a hierarchical structuring in the whole city, from the plot, even from the materials of the building (Kropf 2014) and building to the street and block, neighborhood and the whole settlement. Varying character areas in the city at different levels of resolution emerge as a result of the hierarchical nesting and interplay of urban form elements.

The city is a historical phenomenon that is created and shaped in its socio-cultural context. The urban space provides the physical content to the functioning life of urban society to answer the varying needs of that society (Conzen, 2004, p.49). In Lynch's (1981) words, if human life is a continued state of becoming, then its continuity is founded on growth and development, and if development is a state of becoming more competent and more richly connected, then an increasing sense of connection to one's environment in space and in time is one aspect of growth. Then, the settlement is good as far as it enhances the continuity of a culture and the survival of its people, increases a sense of connection in time and space. The quality of a place develops through the joint effect of the place and the individuals that use it. Thus, the urban landscape is conditioned by culture and history (Whitehand, 1981, p.18)

The dynamic interrelationship between the urban landscape as a man-made object and the society was conceived in Schlüter's (1899) early works in the field of urban morphology. He postulated that the study of urban form should be conducted in relation to the aims and actions of man in the course of history and in its own cultural and natural context. Therefore, according to Schlüter, the urban landscape is viewed as a distinct category of research within the cultural landscape. Had been influenced by Schlüter's and later Bobek's (1927) works, M.R.G. Conzen studied on English towns to built the foundations of historicogeographical approach (Whitehand, 1981, p.11). In his early study on Whitby, Conzen (1958) conceived the urban landscape as an educational asset that provide the society a sense of continuity in its historicity. The historical and cultural development of the city influences its character through different development phases, in which the actions and attitudes of the inhabitants leave many relict forms. As new forms are added to the existing forms in the urban landscape in its historical and cultural development, the 
built environment becomes the objectivation of the human spirit, or genius loci, of that society (Conzen, 1975).

In this framework, urban landscape is not a static entity, or simply the container of events. It is not a ready-made thing; it is constantly evolved through endless maze of relations and interactions in the complexity of morphological processes. It is a place for the ceaseless state of movement and change within the cultural setting and it signifies the continuity of that culture, in which it is continuously reshaped. It embodies the past and present endeavours of the residents that had been living and using the space itself

Hence, the city is a dynamic unity that is reproduced through the articulation of ever-changing forms. It is in a continuous state of becoming and change through the morphological processes of accumulation, adaptation and replacement. Then, the city itself is manifested as a palimpsest through accumulation of forms in its historical development (Conzen 2004, p.68-70). The interaction of the basic elements of urban form - plots, buildings and streets (Barke 2015, Conzen, 1969 [1960], Oliveira 2016, Kropf 2017, Whitehand 2001)- in their context produces the uniqueness of any settlement. Combination of these elements constitute three systematic form complexes, namely town plan- the topographical arrangement of the urban built environment to form the street system, plot pattern and building pattern, building fabric -the three-dimensional composition and arrangement of buildings, and land and building utilization -the functional categories for the use of plot (Conzen, 1969). Within the hierarchical structuring of the morphological elements of urban form, the town plan contains the general frame of land utilization pattern, and land-use units in turn contain the building pattern (Conzen, 1975), while the component forms, such as fringe belts, plot series and character areas are recognized through different levels of solution within the interplay of the elements of urban form in their hierarchical nesting (Barke 2019). This accumulation of forms in its historical and cultural development and interrelation between the morphological elements that resulted in different levels of resolution in various ranks in the hierarchical structure give the city its unique character, diversity and complexity.

In this context, the city is the organic unity, created through its interrelating and interlocking parts to result in a coherent wholeness (Alexander et al, 1987). A successful city can be constructed through the consistent relationships between the morphological elements of urban form within their hierarchical nesting. Therefore, a successful city or a part of the city can only 
be formed through recalling and acknowledging the historicity of urban forms and their dialectical interplay to produce a coherent whole. The management of changes to urban form must be considered within the varying needs, expectations and value judgement of the society to comprehend the city as a whole. Urban morphological research is conducive to analyze the cyclical nature of urban growth, the internal processes of adaptation and redevelopment and the roles of various agents in the production of urban forms, and to provide ideas for the future developments and their management (Whitehand 2001). 'Through the detailed study of urban form, both of the present and the past, we learn both what we should not do and how we can do things better' (Barke, 2018, p.11).

Thus, a detailed study on how urban forms does not have solely a descriptive nature, but it also includes a more interpretative and explanatory nature through understanding, identification and recognition of the processes that shaped the urban landscape. Identification and characterization of changing processes in the urban landscape through morphological methods avail the professionals to understand the very nature of the making of urban forms (Whitehand, 2009). It is also conducive to professionals to develop proposals to intervene into the urban space and to manage the urban change. It provides a rational basis for successful management of urban landscape (Conzen, 1975).

\section{Management of Changes through Urban Development Plans}

The changes to urban form occur in various scales within the hierarchical nesting of morphological elements, and they are reflected in modifications in urban pattern. Any change in the hierarchy or roads, open space system, and distribution of functions among the whole city at a major scale; arrangement of street-blocks, plot series as well as plot pattern and building pattern at a medium scale; and the height, facade and materials of buildings and their disposition within the plot at a minor scale will give effect to any change in the character of a city.

From the morphological perspective, the planner should develop principles about the shaping of urban form in relation to its morphological elements within the hierarchical structure. That is not to focus solely on the physical restructuring of urban form. Rather, the planner should bear on his/her mind that the city (urban space) is a socially constructed phenomenon, and it should be created and shaped within its cultural context. Any change to urban form should be made with reference to the cultural and 
historical continuity and hierarchical nesting of urban forms. That is to say, the 'good city' is the one in which the continuity of its complex structure is maintained while progressive change is permitted (Lynch 1981). Such a view requires to develop sitespecific decision on how the plots, buildings, plot series, blocks, street systems should develop within the part-to-whole relationship of urban form elements. In other words, the planner should develop responsive planning instead of insensitive planning through employing morphological investigations into urban form.

Oliveira (2006) points out that such a morphological perspective was developed during the planning of Porto, Portuguese, between 2001 and 2006, in which ten different urban tissues were identified and taken into consideration as the basis for developing context-based regulations. The plan and its morphological approach were utilized in order to maintain the character of Porto despite the incomplete understanding of some actors (Oliveira et al 2014). However, Porto example seems to be an exception within the whole Portuguese planning system through its eagerness to employ morphological insights into the management of urban change (Oliveira and Sousa 2012). Other cases from different cultural contexts also reveal that utilization of a morphological perspective in planning is very rare. In the plan of St Gervais-les-Bains, France, the building types are designed in relation to the natural characteristics of the site through setting relations between buildings and topography of the site (Samuels 1997). The morphological analysis of Mery-la-Bataille, France provides opportunities to develop planning decisions for different character areas in the city (Kropf 1996). The character of urban areas were at the very center of morphological investigations to develop responsive planning approaches in the historic core of Antequerra, Spain (Barke 2003), Bath, England (Kropf and Ferguson 2014) and Chelmsford, England (Hall 2008). These examples show that it would be possible to develop a morphological perspective in planning through employing a formbased approach to have a responsive planning as an alternative to the functional approach of insensitive planning.

\section{A Morphological Assessment on Turkish Planning}

Since the morphological perspective focuses on the hierarchical nesting of form complexes and the patterns that are produced through the interrelationships between elements of urban form, the morphological assessment of planning is also conducted within a consistent part-to-whole relationship between urban 
elements at various scales -major, medium and minor- in the hierarchical structure of the city. That is to say, the plans are questioned whether they were able to produce the organic unity through the relationship of urban elements with the proposed planning decisions. Therefore, the urban development plans are supposed to present an urban structure through road network and open space system, while supposing street and block types at the medium scale and plot and building patterns at the minor scale.

Although the results of any other similar studies are required to endorse, the study on Çamlıbel, the residential quarter in Mersin, Turkey, evidenced that residential accretions to the historic quarter of Turkish cities ran through three consecutive redevelopment phases during the centennial period after declaration of Turkish Republic in 1923 (Ünlü and Baş 2017). The first period, from the early decades of new Republic until 1960s, experienced the widespread emergence of single-family house in relatively large plots and gardens. In the second phase, apartment blocks began to emerge as new building types in the derivative plots, whilst the single-family houses on the plot heads were replaced by this new type in the third phase. As a further phase, in 2000s, housing estates began to appear in the newly developing peripheral areas. However, what was the role of planning in this transformation?

It was the idea of 'creating a new future' (Keskinok 2006) to generate a new society in the first decades of the young Turkish Republic, namely early Republican period between 1923 and 1945. When Hermann Jansen, the German architect-planner, won the international planning competition for planning of Ankara, the new capital of the country, a low-density city with single-family houses was taken as a model to develop cities (Tankut 1993, p.37). The garden city idea well suited to the shaping of new urban environments through its main principle of the progressive rejection of the big city, the desire for small town living and working, the search for real involvement in common affairs' (Ward 1992, p.1). Since Jansen was influenced by garden city idea, he adopted its principles to new residential quarters (Akcan 2012, p.41).

From a morphological perspective, Jansen dealt with the elements of urban form in a hierarchical nesting throughout the major, medium and minor scales. He used this method in all plans, prepared in Turkey for Mersin, Tarsus, Adana, Ceyhan, Gaziantep, 
and Izmit after planning of Ankara. Prior to these plans, he applied his principles comprehensively in Berlin Plan, of which he won the planning competition in 1910. In fact, he developed his planning approach during his professional life that began in Germany, where he was influenced by Camillo Sitte (Borsi 2015, Bozdoğan 2001, Tankut 1993).

At the major scale, he proposed a road hierarchy and open space system, in which fringe belt-like morphological units existed. It is not clear whether he was aware of the fringe-belt idea, nonetheless there is a probability that he was following the developments in urban morphology during his work as a professor at Berlin Technical University (Saban Ökesli 2009), where the pioneering studies of Schlütter emerged as well as the incipient fringe-belt concept, Stadtrandzone was used by Louis (1936) in order to explain the morphological structure of Berlin. Jansen combined recreation areas and public institutions as well as industrial zones to have a fringe belt-like structure, girdling the city centre. At the medium and minor scales, Jansen proposed plot pattern, building pattern, and a new block type and street type, as well as architectural plan types in combination. He also visualized the urban environment, he envisaged, through three-dimensional drawings, as subordinate documents to the development plans. At the medium scale, the main morphological unit for Jansen was the neighborhood, probably under the influence of Siedlungen approach of German planning (Rykwert 2010). In his plans, he separated neighborhoods from each other via open spaces of large-scale public parks, while they are also connected to the fringe belt-like structure to make a consistent whole of open space system. In the neighborhoods, at the minor scale, he developed decisions on plot sizes, in which a building would be located at the plot head with a large garden at the back. It was the residential street (wohnstrasse), around which the plots come together and create a morphological unit, similar to the use of 'close' and plots around it by Raymond Unwin, who also was highly influenced by the ideas of Sitte, in designing the Hampstead Garden Suburb (Panerai et al. 2004, p.45).

Jansen developed a morphological perspective in preparation of his plans and aimed to produce the city as a coherent whole through nesting of urban form elements from the minor to major scales (Figure 1). His approach influenced the planning practice of early Republican period, when the architect-planners undertook the plan-making process as a part of republican aims to reach the desired, modern and western-oriented future (Bozdoğan and 
Akcan 2010, p.8). Many similar plans were prepared, especially after the issue of Buildings and Regulations Law in 1933.

Figure 1. Jansen's drawings on the architectural plans, facades, building types, plot types, and their togetherness in a hierarchical nesting. Top left: a detail from a neighborhood plan "Neugestaltung Berlin - Gatow" (Source: TU Berlin Architekturmuseum Inv. Nr. 22469), top right: wohnstrasse, buildings and the block "Gesamtbebauungsplan Ankara" Source: TU Berlin Architekturmuseum Inv. Nr. 22982), bottom left: plot pattern in Charlottenborg-Nord, Berlin (Source: TU Berlin Architekturmuseum Inv. Nr. 20785), bottom right: building types in Berlin (Source: TU Berlin Architekturmuseum Inv. Nr. 21127)

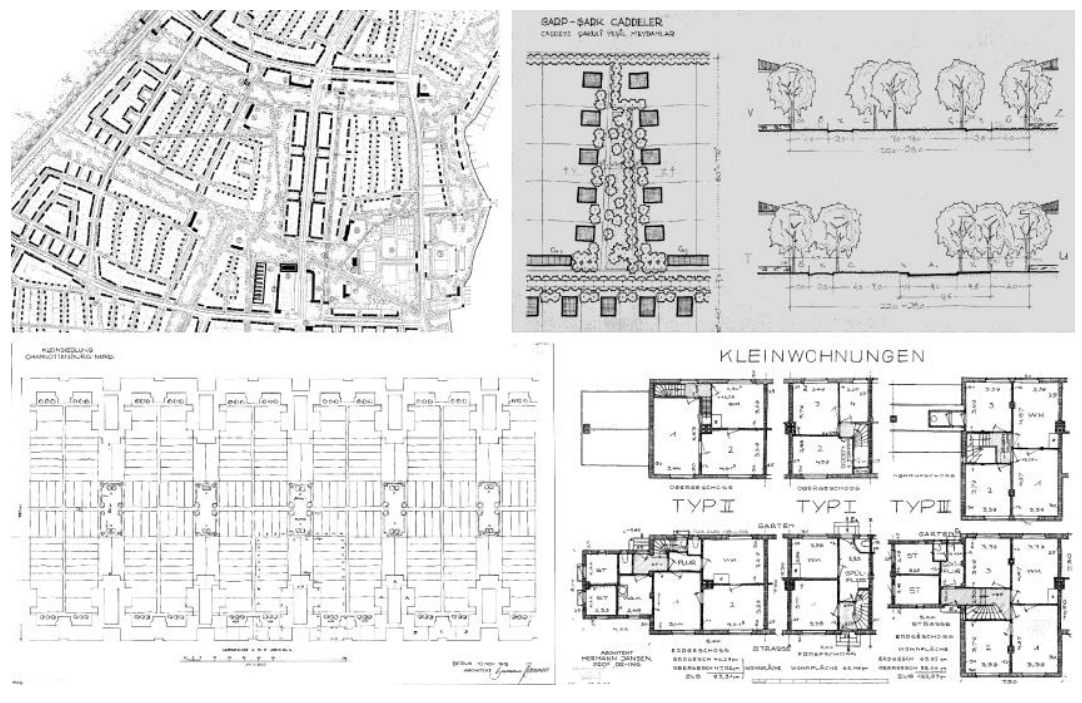

Following the early Republican period, due to the rapid population increase, Turkish cities experienced from 1950s to 1980s, the priority was given to control the urban sprawl to the outskirts, and to establish a new urban structure at the major scale. In this vein, the planners utilized statistical methods to cope with the new social and economic problems, besides the physical ones, and employed transportation models to interact with the rapidly growing city. As much attention was given to controlling urban growth, the inner city was facing a transformation process, which was resulted in emergence of apartment block as a new building type. Although the apartment block was not a new phenomenon that it was firstly appeared in Istanbul during the late-nineteenth century as a symbol of Western way of life, when modernization of urban fabric was at stake (Bilgin 1999, Öncel 2010, Sey 1998a), it became the dominant building type after the early Republican period in response to the problems to find new places for accommodation to the newcomers from rural to urban areas (Balamir, 1975; Günay, 2005; Sey, 1998b). The apartment block replaced the single-family house of the early Republican period, following its first appearance in the derivative plots (Ünlü and Baş 2017).

In this process, development plans are sought to be the tools to produce the built environment in a repetition of the apartment block as an already established building type. They aimed to control the morphological processes at the minor scale through a quantitative approach, focusing on solely building heights, building types, setbacks and street widths (Figure 2). In this perspective, the focus is held upon production of the freestanding 
buildings, regardless of their interaction to other morphological elements of urban form in a part-to-whole relationship. The planners developed decision for the width of streets without imagining what qualities those streets would acquire; or they determined the height and type of buildings without thinking of the structure of the plot they would located in.

Therefore, the development plans and thus planners of the period between 1950s and 1980s failed to notice the organic unity of the city that would function through the hierarchical nesting of morphological elements of urban form. The concentration was on the single building at the minor scale, and on the road network and open space system at the major scale without or little attention to how to interrelate them to each other. In the absence of interrelationship of urban form elements, creation of the urban pattern was reduced to rapid replacement of old building types with apartment blocks within the plots, created for the singlefamily houses in the previous period. Increasing building heights and coverage, and production of identical buildings led to homogenization of the urban landscape at the minor scale that resulted in emergence of 'static urban pattern'.

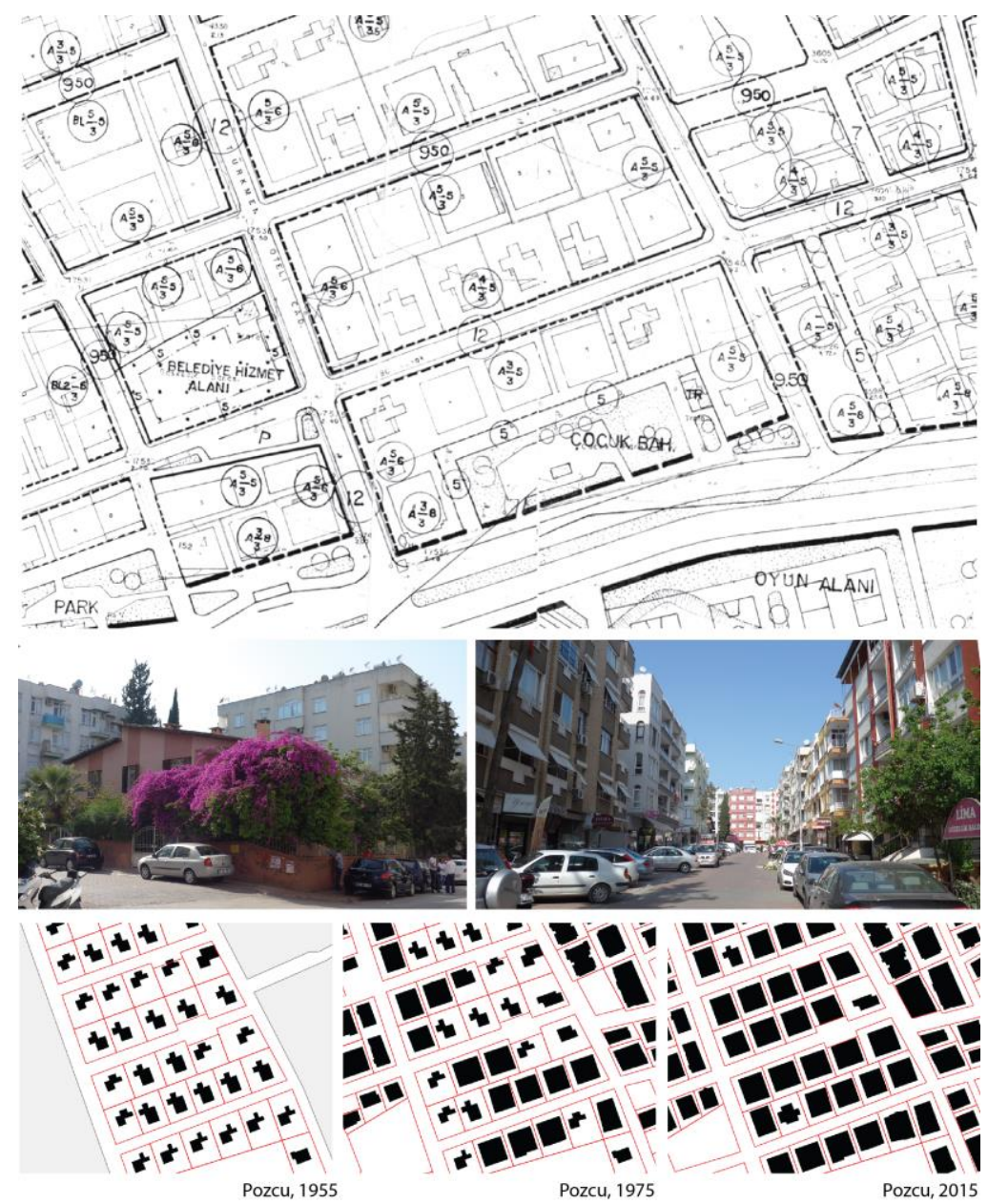

Figure 2. The apartment block began to emerge as a dominant building type in the development plans, following the early Republican period: Development plan for Mersin, 1986, a detail from Pozcu residential district and the apartment blocks that replaced the single-family houses (personal archive). The letters in the circle stand for building types (A for detached, B for attached, BL for semi-detached and row houses) while the numbers refer to the number of storeys. 
The certainty of development plans and the quantitative approach embedded in plans, and emergence of mediocre (Tibbalds 2001) incoherent (Alexander 1966, Hedman and Jaszenski 1984) fragmented (Urban Task Force 1999) sacked (Jacobs 1961) faceless (Conzen 1975) ugly (Lynch 1960) dull, uninteresting and soulless (Cullen 1961) city through the static urban pattern steered the planning system to seek more flexibility. By this way, more discretion would be given to the decision-making process, in which the relationship between the plan and development decision is weakened (Booth 1995). In this vein, the content of development plans also changed from a rigidity that control quantitative measures, such as building heights, setbacks, road widths etc., to a flexibility that controls only the FARs (floor area ratio) of the proposed development. Therefore, in the last period that began during 1990s, but accelerated in the 2000s, control of the morphological characteristics has been dominated by the use of FAR in development plans. This brought about a new building type in the residential environments, called 'campus type' by Scheer (2010) since it is also widely seen also in the US cities. This type utilized a larger plot than the ones that were produced in the previous periods. This new plot consists of usually more than one building with its large garden and social utilities, such as playground, swimming pool and sports areas.

Although the new plot pattern and building pattern seem to find solution to the problems of the static urban pattern, the focus is still held upon the freestanding buildings. This time, the strategic control of a wider area is failed and the control is reduced to the plot, of which the area is usually equals to the building block, and the total construction area of buildings without any concern on other morphological element of urban form. The quantitate approach and focus on production of freestanding buildings remained as a dominant view in preparation of urban development plans during replacement of certainty and rigidity of previous periods by flexibility of the new period. The resultant form is the collocation of indifferent housing estates in various plots, having diverse building types, buildings height, materials, architectural styles, together which produced an indistinct urban pattern in the residential environments (Figure 3). 


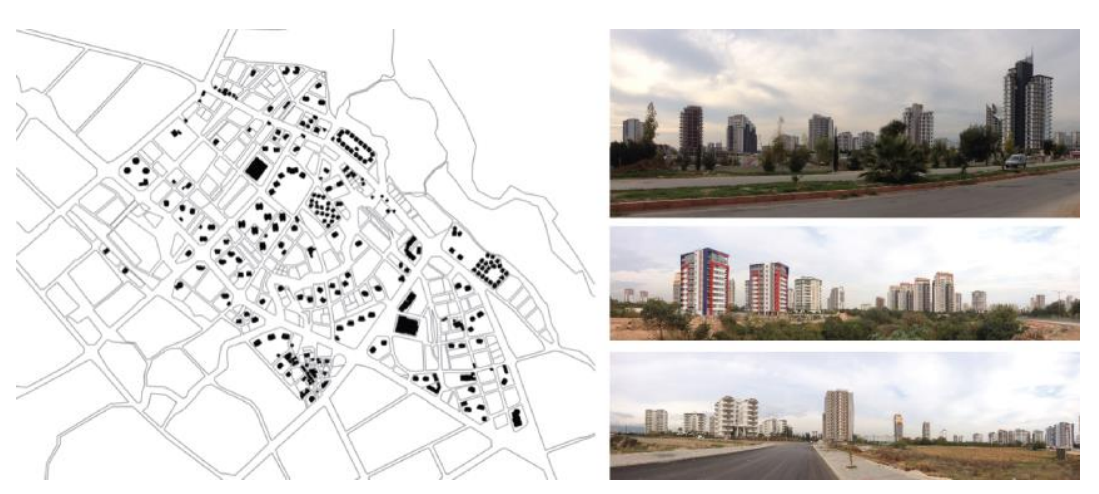

CONCLUSION

This study is triggered with questioning the awareness of planners on the intrinsic qualities of the built environment in shaping of urban form. It has suggested a framework to develop such an evaluation, which is based on three basic principles: the historicity of urban forms, the hierarchical nesting of urban form elements, and their reconciliation within a complex interaction with each other in a part-to-whole relationship. Functioning of the city through these three principles results in urban patterns and character areas in various scales (from minor to medium and major) at different levels of resolution. Many successful cities, such as Kyoto, Manhattan, Siena (Alexander 1966) produced their coherent whole (Alexander et al 1987) through the reconciliation of urban form elements in their historicity and hierarchical nesting congruously.

In this vein, the attitude of planners in Turkey is examined in relation to the evolution of planning practice during the centennial period after proclamation of the new Turkish Republic in 1923. It was scrutinized whether the planners were capable and aware of the entirety of urban form in its historicity and hierarchical nesting. Although it is not clear that the professionals conducted morphological investigations into urban form, It has been discerned that they were in search of the morphological unity of urban form elements in the early Republican period and they employed a morphological perspective to shape the built environment. They envisaged the city within its wholeness from minor to medium and major scales, and suggested plot pattern, building pattern, street system and street and block types at the minor and medium scales as well as road network and open space system at the major scale. And it was the concern of planners to think on how morphological elements of urban form would reconcile and produce a total effect on the living of society.
Figure 3. The indistinct urban pattern and housing estates as a result of the dominant use of FAR in development plans during 2000s. 
This morphological perspective was broke down in the following periods, basically in the second half of nineteenth century. The main focus was held upon on structuring of the city at the major scale, while the freestanding buildings were the basis of production of the built environment with the help of development plans. Production of the identical apartment block as a dominant building type at the minor scale was at the forefront in the shaping of urban form in the second phase. The insensitive planning that depends on ignoring the morphological elements of urban form was highly employed by the planners of the period. The quantitative approach, embedded in this type of planning, conduced to emergence of a static urban pattern throughout the city, which became focus of critics by many professionals.

Flexibility as a response to the rigidity of development plans could not change the quantitative approach and the focus on freestanding buildings, embedded in planning. Rather, it has deepened the problem of insensitive planning through loosening the morphological controls over the shaping of urban form. Freestanding buildings retained their importance as the most important element of urban form. They became to be shaped in a more quantitative way through employing only FAR (floor area ratio) measures, result of which is an indistinct urban pattern. Separation of urban form elements from each other and their isolation in different scales engendered emergence of a fragmented city.

This study has been an initial attempt to develop a brief discussion about a morphological perspective to be utilized in planning practice. It certainly requires in-depth studies on a plot-by-plot basis. However, at the very least, it is possible to assert that the centennial development of planning practice in Turkey brought to light that the professionals lost their concern on the intrinsic qualities of urban form, on how it is evolved historically, and on how its elements are related to each other. They abandoned themselves to the relative ease of application of insensitive planning with high confidence on the decency and convenience of procedural functioning of planning. It reveals that there is need for further studies to continue discussing on a morphological perspective that would take into account the morphological unity of urban form elements within their interplay in order to develop a responsive planning approach. 


\section{REFERENCES}

Akcan, E. (2012). Architecture in translation: Germany, Turkey and the modern house. Durham: Duke University Press.

Alexander C. (1966). A city is not a tree. Design 206:47-55

Alexander C., Neis H., Anninou A. \& King I. (1987). A new theory of urban design. Oxford University Press, New York

Balamir, M. (1975). 'Kat Mülkiyeti ve Kentleşmemiz' ('The process of ownership fragmentation in Turkish urbanization'), Middle East Technical University, Journal of the Faculty of Architecture 1 (2), 295-319.

Barke, M. (2003). The lifespan of a typological form?. Urban Morphology 15:21-38

Barke, M. (2015). Further thoughts on research and practice in urban morphology: a British perspective. Urban Morphology 19(1):96-99.

Barke, M. (2018). The Importance of Urban Form as an Object of Study. In Oliveira V (ed) Teaching Urban Morphology. Springer, Cham, pp.11-30.

Barke, M. (2019). Why study urban morphology? The views of ISUF members, Urban Morphology 23(2):105-14

Bilgin, İ. (1999). 'Modernization', in Sey, Y. (ed.) Housing and settlement in Anatolia: a historical perspective (Tepe Architectural Culture Centre, İstanbul) 247-361.

Bobek, H. (1927). Grundfragen der Stadtgeographie, Geogr. Anz. 28, 213-24.

Booth, P. (1995). 'Zoning or Discretionary Action: Certainty and Responsiveness in Implementing Planning Policy', Journal of Planning Education and Research (14):103-112.

Borsi, K. (2015). Drawing the region: Hermann Jansen's vision of Greater Berlin in 1910. The Journal of Architecture, 20(1), 47-72.

Bozdoğan, S. (2001). Modernism and Nation Building. Seattle:University of Washington Press.

Bozdoğan, S. \& Akcan, E. (2012). Turkey: modern architects in history. Reaktion, London

Cataldi, G. (2003) From Muratori to Caniggia: the origins and development of Italian school of design typology. Urban Morphology 1:96-99

Conzen, M.R.G. (1958) The growth and character of Whitby. In: Daysh GHJ (ed) A survey of Whitby and the surrounding area. Shakespeare Head Press, Eton, pp 49-89

Conzen, M. R. G. (1960). Alnwick: Northumber- land: a study in town-plan analysis. Institute of British Geographers Publication 27. George Philip, London. 
Conzen MRG (1969) Alnwick, Northumberland: a study in townplan analysis, 2nd edn. Institute of British Geograpers Publication 27. London: Institute of British Geographers.

Conzen, M.R.G. (1975). Geography and townscape conservation. In: Uhlig H, Lienau C (eds) Anglo-German symposium in applied geography. Lenz, Giessen, pp 95-102

Conzen, M. R. G. (2004). Thinking about urban form: papers on urban morphology (Conzen, M. P., ed.). Peter Lang, Bern.

Cullen G (1961). Townscape. Reinhold, New York

$\mathrm{Gu} \mathrm{K}$ (2018). Exploring Urban Morphology as Urban Design Pedagogy. In Oliveira V (ed) Teaching Urban Morphology. Springer, Cham, pp.145-158.

Günay, B. (2005). Türkiye mimarlı̆̆ı: gelenek, yöre, doğu, batı (Architecture in Turkey: tradition, locality, east, west). Şehir Plancıları Odası, Ankara.

Hall, T. (2008). The form-based development plan: bridging the gap between theory and practice in urban morphology. Urban Morphology, 12(1):77-95

Hedman, R. \& Jaszenski, A. (1984). Fundamentals of urban design. APA Press, Chicago

Jacobs, A. \& Appleyard, D. (1987). Toward an Urban Design Manifesto, Journal of the American Planning Association, $53: 1,112-120$

Jacobs, J. (1961). The death and life of great American cities. Vintage Books, New York

Keskinok, Ç. (2006). Şehirciliğimizin yüzyılını değerlendirirken (On the evaluation of a century of our urbanism). In: Keskinok Ç (ed) Kentleşme siyasaları (Urbanization policies). Kaynak, Istanbul, pp 213-218

Kropf, K. (1996). Urban tissue and the character of towns. Urban Design International 1:247-263

Kropf, K. (2014). Ambiguity in the definition of built form. Urban Morphology 18(1):41-57

Kropf, K. (2017). The handbook of urban morphology. Chichester, Wiley

Kropf, K. \& Ferguson, P. (2014). City of Bath morphological study. Built Form Resource, Oxford

Larkham, P.J. (2006). The study of urban form in Great Britain. Urban Morphology 10(2):117-141

Loius, H. (1936). Die geographische Gliederung von Gross-Berlin', in Louis, H. and Panzer, W. (er.) Landerkundliche Forschung: Krebs-Festschrift içinde (s.146-171), Engelhorn, Stuttgart.

Lynch K (1960) The image of the city. MIT Press, Massachusetts Lynch K (1981) Good City Form, MIT: Cambridge Massachusetts Moudon, A.V. (1997). Urban morphology as an emerging interdisciplinary field. Urban Morphology 1(1):3-10 
Oliveira, V. (2006). The morphological dimension of municipal plans. Urban Morphology 10(2):101-113

Oliveira, V. (2016). Urban morphology: an introduction to the study of the physical form of cities. Springer, Dordrecht

Oliveira, V. \& Sousa, S. (2012). Urban morphology in planning practice. Urban Morphology 16(1):80-82

Oliveira, V., Silva, M. \& Samuels, I. (2014). Urban morphological research and planning practice: a Portuguese assessment. Urban Morphology 18(1):23-39

Öncel, A. D. (2010). Apartman: Galata'da yeni bir konut tipi (Apartment: a new housing type in Galata). Kitap, İstanbul.

Panerai P., Castex J., Depaule, J. C. \& Samuels, I. (2004). Urban forms: the death and life of the urban block. Oxford: Architectural Press.

Rykwert, J. (2010). The Seduction of Place. Oxford: University of Oxford Press.

Saban Okesli, D. (2009). Hermann Jansen's planning principles and his urban legacy in Adana. METU Journal of the Faculty of Architecture, 26(2), 45-67.

Samuels, I. (1990). Architectural practice and urban morphology. In: Slater TR (ed) The built form of Western cities. Leicester University Press, Leicester, pp 415-435

Samuels, I. (1997). A typomorphological approach to design. Urban Design International 4:129-141

Samuels, I. (2019a). Research and Practice, in V. Oliveira (ed.), J.W.R. Whitehand and the Historico-geographical Approach to Urban Morphology, Springer, Cham, p. 115131.

Samuels, I. (2019b). Mind the gap, Urban Morphology 23(2):16970

Scheer, B.C. (2008). Urban morphology and urban design. Urban Morphology 12(2):131-133

Scheer, B.C. (2010). Evolution of urban form: typology for planners and architects. APA, Chicago

Schlüter, O. (1899). Bemerkungen zur Siedelungs-geographie, Geographische Zeitschrift, 5, 65- 84.

Sey, Y. (1998a). 'Cumhuriyet döneminde Türkiye'de mimarlık ve yapı' ('Production of architecture and building during the Republican period'), in Sey, Y. (ed.) 75 yılda değișen kent ve mimarlık (75 years of urban and architectural change) (Tarih Vakfi, İstanbul) 25-40.

Sey, Y. (1998b). 'Cumhuriyet döneminde konut' ('Housing during the Republican period'), in Sey, Y. (ed.) 75 yılda değişen kent ve mimarlık (75 years of urban and architectural change) (Tarih Vakfi, İstanbul) 273-300.

Tankut, G. (1993). Bir bas, kentin imarı (Development of a capital city). Anahtar, istanbul 
Tibbalds, F. (2001). Making people-friendly towns. Taylor \& Francis, London

Trancik. R. (1986). Finding Lost Space: Theories of Urban Design. New York: Van Nostrand Reinhold.

Urban Task Force (1999). Towards an urban renaissance. DETR, London

Ünlü, T. \& Baş, Y. (2017). Morphological processes and the making of residential forms: morphogenetic types in Turkish cities. Urban Morphology 21(2):105-122

Ward, S. (1992). The Garden City introduced. Ward, S. (Der.) The Garden City: Past, present and future içinde. Oxon: Spon.

Whitehand, J. W. R. (1981). 'Conzenian ideas: extension and development', in Whitehand, J. W. R. (ed.) The urban landscape: historical development and management. Papers by M. R. G. Conzen Institute of British Geographers Special Publication 13 (Academic Press, London) 127-52.

Whitehand, J.W.R. (2001). British urban morphology: the Conzenian tradition. Urban Morphology 5(2):103-109

Whitehand, J.W.R. (2005). The problem of anglophone squint. Area 37:228-230

Whitehand, J.W.R. (2007). Conzenian urban morphology and urban landscapes. In: Proceedings of the 6th international space syntax symposium, Istanbul

Whitehand, J.W.R. (2009). The structure of urban landscapes: strengthening research and practice. Urban Morphology 13(1):5-27

Whitehand, J.W.R. (2012). Issues in urban morphology. Urban Morphology 16(1):55-65

Whitehand, J.W.R. (2019). ISUF and Urban Morphology: 25 years on and counting, Urban Morphology 23(2):103-4

\section{Resume}

Tolga Ünlü took his bachelor, graduate and PhD degrees at the Department of City and Regional Planning, Middle East Technical University. His research is focused on urban morphology, urban design and planning practice with a particular attention on urban growth and development of fringe belts, and on the relationship between research and practice in urban morphology and planning. Had articles and book chapters on physical development and planning history of Turkish cities as well as their morphological transformation. Has been working at the University of Mersin since 2006 as a member of the Department of City and Regional Planning. 